Michal Liška, M.A.,

Postgraduate student, Faculty of Law, Masaryk University,

Czech Republic

Petra Snopková, M.A.,

Postgraduate student, Faculty of Law, Masaryk University,

Czech Republic

\title{
VAT CONTROL STATEMENT \& ELECTRONIC RECORD OF SALES
}

\section{Introduction}

$\mathrm{T}$ owards the end of 2013, the European Commission issued "An Action Plan to strengthen the fight against tax fraud and tax evasion" in which the Commission describes some measures that should be taken by Member States to can help reduce tax evasion and improve tax collection. The Commission proposed in particular to improve the existing cooperation between Member States and their tax administrators and to intensify the use of information exchange.

The Commission also proposed to adopt a proposal for the rapid reaction mechanism against VAT fraud, which was already introduced by Council Directive 2013/42/EU of 22 July 2013 and which allows the Commission to very quickly authorize a Member State to adopt derogation measures of a temporary nature in order to deal with cases of sudden and massive fraud with a significant financial impact. ${ }^{1}$

Within the framework of obligations imposed by EU law, the Czech Republic created two conceptual legal institutions in the form of the VAT Control Statement and Electronic Record of Sales. The authors attempt to acquaint readers of this paper at least in the basics of these two innovations introduced in the Czech Republic.

\section{VAT Control Statement}

The first of the newly-established legal institutions to help in the fight against tax frauds is the VAT Control
Statement. The VAT Control Statement was introduced into Czech law by Act no. 360/2014 Coll., amending Act no. 235/2004 Coll., On Value Added Tax, as amended (hereinafter "the VAT Act"), and other related laws, with some provisions, among others, related to the recently introduced obligation to submit the VAT Control Statement and the withdrawal of the exemption for natural persons from mandatory electronic filing of forms. The obligation to submit the VAT Control Statement applies to selected taxpayers, while meeting statutory requirements from $1^{\text {st }}$ January 2016.

VAT Control Statement is a new legal institution introduced into the VAT Act as a requirement for keeping records relating to tax liability and has been proposed in order to improve tax collection, reduce tax frauds on VAT, and thereby strengthen the position of decent taxpayers.

The VAT Control Statement is generally submitted by taxable persons registered for VAT in the Czech Republic, while it is not clear whether they are a domestic or foreign entity. The obligation to submit the VAT Control Statement is linked to the emergence of one of the following legal facts in the so-called reporting period:

a) domestic taxable supplies or receipt of advance payment,

b) domestic acquisition of goods/services or providing of advance payment,

c) received transactions from which the acquirer is obliged to declare VAT according to article $108 \mathrm{sec}$ tion $1 b$ ), c) of the VAT Act, 
d) special scheme for investment gold:

- received Intermediary Service for which VAT is applied according to Article 92 section 5 of the VAT Act;

- supply of VAT exempt investment gold for which the taxable person registered for VAT is entitled to deduct VAT pursuant to Article 92 section 6 b) and c), or

- production of investment gold or transformation of gold into investment gold according to Article 92 section 7 of the VAT Act.

The following are not obliged to submit the VAT Control Statement:

a) a person who is not a VAT payer,

b) an identified person,

c) a payer who has not carried out or has accepted no performance during the reporting period (in the reverse charge procedure) or a payer who does not claim any deduction of tax from the received supplies in normal mode,

d) a payer who carries out only exempt taxable supplies without the right of deduction of tax (according to Article 51 of the VAT Act). ${ }^{2}$

Article 101d of the VAT Act also provides that the taxpayer shall state the required data needed for tax administration in the VAT Control Statement. Taxpayers must submit the VAT Control Statement only electronically to the email address of the Mail Room of the tax administrator in question in the format and structure set by the tax administrator.

The deadline for submission of the VAT Control Statement was originally laid down uniformly for all taxpayers - within 25 days after the end of the calendar month. During the legislative process the diversity of the taxable period for VAT was taken into account and therefore we can find a dual deadline for submission of the VAT Control Statement: the legal entity submitting the VAT Control Statements every month (within 25 days after the end of the calendar month), and natural persons within the deadline for submitting the tax return (within 25 days after the end of the month or quarter). The first obligation to submit the VAT Control Statement for monthly VAT payers was on $25^{\text {th }}$ February 2016, and quarterly payers will first submit the VAT Control Statement no later than on $25^{\text {th }}$ April 2016.

In connection with the obligation to submit the VAT Control Statement, before its introduction the high administrative burden on businesses was mentioned. However, as evidenced by data from the first administration, about 87 percent of monthly taxpayers submitted the VAT Control Statement, while only a negligible 1 percent of them did not meet the requirement of the form or structure. Only 5 percent of the mandatory monthly payers who were obliged to submit the VAT Control Statement did not submit it, and they were called on to do so by the tax administrator in accordance with the provisions of Article 101g of the VAT Act. ${ }^{3}$

According to the explanatory report, the VAT Control Statement is another legal institution to combat tax evasion because tax administrators will have quick access to data relating to VAT and can cross-check the data from the VAT Control Statement with that filed in the tax returns. Tax administrators will have certain data from the VAT Control Statement in the time of its filing (if the legal requirements of filing will be fulfilled) which enable it to analyze and identify possible connections of payers. After pairing is done, the tax administrator can theoretically expose the taxpayer who improperly claims the deduction of tax, and after that the tax administrator can focus his inspections on him. ${ }^{4}$ However, we can say that given the frequency of submission of the VAT Control Statements, pairing selected data from the VAT Control Statement with that from the tax returns on VAT and pairing the VAT Control Statements with each other will become an effective control mechanism, but on the other hand it will increase the burden of individual workers. So it is questionable whether it will be possible to solve the situation with the VAT Control Statement in the short time limits associated with it.

The VAT Act also provides for a penalty for default obligations provided by law relating to the VAT Control Statement. Currently these are the most frequently discussed penalties provided in Article 101h of the VAT Act, which are implemented very strictly. Recently the Czech Government approved the proposal of the Ministry of Finance to mitigate the impact of these penalties. ${ }^{5}$ According to the available version of the draft amendment to the VAT Act ${ }^{6}$, 
the main proposal is a supplement of tax remission, which will cover penalties arising from the law in a fixed amount of CZK 10 000, CZK 30000 and CZK 50 000. The tax payer will be entitled to ask the tax administrator for remission of tax within 3 months from the date of legal force of the tax assessment which set the obligation to pay the penalty. The tax administrator may waive this wholly or partly if there has been a failure to submit the VAT Control Statement on grounds that can be justified by the circumstances of the case. There is thus created a similar structure as the tax remission of interest on late payment and interest on the respite amount described in Article 259b of Act no. 280/2009 Coll., The Tax Code, as amended (hereinafter "the Tax Code"). Generally, the institution of remission of accession of a tax is governed by Instructions D-21 to remission of accession of a tax from the General Financial Directorate ${ }^{7}$, which sets the justifiable reasons of tax remission, but only in relation to Article $259 \mathrm{~b}$ of the Tax Code. Since these internal binding notes are issued mainly because of the unification of the decision of the individual tax administrators, the General Financial Directorate will have to take some measures (amend the Instruction or issue a new one) in the case of approval of the amendment.

However, the draft amendment does not approach the proceedings of the remission of the penalty, so the tax administrator will have to proceed under Article 259 et seq. of the Tax Code. These provisions, among others, determine that remedies are not applicable against the decisions on remission of accession of a tax, i.e. appeal against this decision is not allowed and it can be contested only by supervisory measures (e.g. a review of the decision if it was issued contrary to the law).

In addition to the institution of remission, the draft amendment stipulates the possibility of exemption from the obligation to pay a penalty in the amount of CZK 1,000: in a situation where the taxpayer is not in delay with other VAT Control Statements in a given calendar year, the tax administrator may take this into account automatically without the need to submit an application by the taxpayer. In addition, according to the Ministry of Finance's recently introduced temporary provisions, a certain transitional period of tolerance will be created in which penalties in the amount of CZK 1,000 formed before the effectiveness of the proposed amendment will expire.
According to the Ministry of Finance, the proposed amendment to the VAT Act should mitigate the impact of penalties for breach of duties related to the VAT Control Statement to the taxpayer and we can assume that taxpayers will use these institutions extensively in the early months after the effectiveness of the amendment (and taking into account the penalties not only then). There are different opinions about the existence of a duty to submit the VAT Control Statement. One of them is the one that it entails a significant increase of administrative burden on the side of taxpayers; however, from the above-mentioned is shown that the administrative burden grows particularly on the side of tax administrators.

In addition to the legal institution of the VAT Control Statement and its sanctioning consequences, in the Czech Republic the taxpayers waited to see protection of the European Convention for the Protection of Fundamental Human Rights (hereinafter "the Convention") for the sphere of criminal and fiscal offenses. ${ }^{8}$ The European Court of Human Rights in the case of Lucky Dev v. Sweden, dated $27^{\text {th }}$ November 2014, application no. 7356/10, spoke in favour of providing "full" protection of Article 4 of Protocol no. 7 to the Convention (hereinafter "the Protocol") of tax entities, to which fell the obligation to pay the penalty under Article 251 of the Tax Code. The European Court of Human Rights, however, did not provide protection only against criminal prosecution of the same offence twice (in tax proceedings and in criminal proceedings), but this decision also brought the possibility for the taxpayers to seek the imposition of lighter penalties for violation of tax laws of a criminal nature. The above-mentioned flows from the fundamental principles which are inherent in the very nature of criminal law ${ }^{9}$, which was confirmed by the European Court of Human Rights in its decision in the case Scoppola v. Italy, which was overcame by the findings made in decisions X v. Germany, Le Petit v. the United Kingdom and Zaprianov v. Bulgaria. One of the legal institutions of a criminal nature as well are the penalties embodied in Article 101h paragraph 1 of the VAT Act. According to the explanatory report ${ }^{10}$, the purpose of these penalties has a similar character as the penalties set by Article 251 of the Tax Code. In light of the above and on the existence of moderating institutions, we can apply conclusions resulting from the jurisprudence of the above-mentioned to institute these penalties. We can summarize that the planned amendment of the VAT Act will bring the possibility of moderation by reference to the conclusions made by the European Court of Human Rights to taxpayers. 


\section{Electronic Record of Sales}

The Electronic Record of Sales is an instrument prepared by the Ministry of Finance in the area of transactions in cash, which should ensure a continuous flow of information needed to administer various types of taxes in relation between taxpayers and the tax administration. The current state supports the negotiation of taxpayers seeking to conceal facts relevant to the administration and collection of taxes and distortion of the actual picture of the total tax liability, which is reflected significantly in both the statement of the amount of the total tax liability and the final amount of the tax collection. Such a situation may be considered as undesirable for reasons on the side of effective administration of public finances and those on the side of private (natural or legal) persons.

The Ministry of Finance therefore proposes that the obligation to make the records of set sales should fall significantly on all compulsory subjects carrying out set recorded transactions in the prescribed form. The Ministry wants to set the situation where only the minimum absolute (complete exemption from the regime of record of sales) and procedural (submission to other than the standard regime of record of sales) exceptions are accepted.

Sales would be subjected to electronic records if there are three statutory elements cumulatively fulfilled:

1. sales are made between statutory bodies (subjective element),

2. the sale took place under statutory circumstances (material element),

3. the sale (payment) was conducted in the prescribed manner (formal element). ${ }^{11}$

Czech regulation is not unique in the European area. An institution similar to the Electronic Record of Sales was introduced by neighbouring states too. The Slovak Republic established the obligation to use a special electronic cash register with fiscal memory since $2009^{12}$ and in April 2015 changed its system so that nowadays selected providers of services can continue to use the current electronic cash register, or they can join the "virtual cash register" via the Internet (a similar system to the Czech Electronic Record of Sales). Some similarity can also be found in the forthcoming mechanism of inspection through the institution of the so-called lottery of receipts which is part of the system in the Czech Republic. Because of the possibility of the announcement of the lottery of receipts, the Czech Republic should use the experience of the Slovak Republic, where it was a relatively effective control mechanism after the first announcement, because people have a certain motivation, it was something new, and non-routine. Electronic evidence was also introduced in January 2016 in Austria, where, unlike the Czech Republic, the seller must issue a receipt to the customer and he has an obligation to keep it. Each customer shopping in a store with a cash register must keep the receipt until it goes out of business, where he can be called for submission of the receipt.

\section{$\underline{\text { Abstract }}$}

In the Czech legal order some news related to the fight against tax fraud on value added tax (hereinafter "VAT") appeared at the beginning of 2016. The authors attempted to acquaint readers with two of the most controversial legal institutions - the VAT Control Statement and Electronic Record of Sales. We can enunciate about the VAT Control Statement that it is a legal institution which can portray matching and chaining of VAT taxable supplies in the framework of "value added" to the tax authority. Short-term practice speaks in favour of the suitability of implementation of this legal institution, which is described below. It is necessary to point out that the electronic record of sales is a very debatable topic in the Czech Republic nowadays and after some time we can find out how effective a tool it has become in the fight against tax fraud. Unlike other European countries' systems of electronic record, the Czech one lays fewer obligations on taxable persons registered for VAT and their customers. It can be summarized that in the case of these legal institutions, while theoretically they serve a legitimate objective and laudable purpose, only practice will show whether the administrative burden imposed on tax payers is reasonable and whether the VAT Control Statement and Electronic Record of Sales will become effective legal institutions in the fight against tax fraud. 


\section{BIBLIOGRAPHY}

\section{Literature and online sources:}

1. Evropská úmluva o lidských právech: komentár. 1. vyd. Praha: C. H. Beck, 2012.

2. Důvodová zpráva $\mathrm{k}$ návrhu zákona, kterým se mění zákon č. 235/2004 Sb., o dani z přidané hodnoty, ve znění pozdějších předpisů, a další související zákony. Poslanecká sněmovna Parlamentu České republiky, sněmovní tisk č. 291 [online]. Accessed at 28.2.2016. Available online at: http://www.psp.cz.

3. Důvodová zpráva $\mathrm{k}$ návrhu zákona, kterým se mění některé zákony v souvislosti s přijetím celního zákona. Poslanecká sněmovna Parlamentu České republiky, sněmovní tisk č. 717 [online]. Accessed at 28.2.2016. Available online at: http:// www.psp.cz.

4. Kdo podává kontrolní hlášení? Finanční správa České republiky [online]. Accessed at 28.2.2016. Available online at: http://www.financnisprava.cz.

5. Kontrolní hlášení: aktuální statistiky z prvního podávání. Finanční správa [online]. Finanční správa České republiky. Accessed at 28.2.2016. Available online at: http://www.financnisprava.cz.

6. Sdělení Komise Evropskému Parlamentu a Radě: Akční plán pro posílení boje proti daňovým podvodům a únikům ze dne 6.12.2012. Evropská Komise [online]. Accessed at 28.2.2016. Available online at: http://ec.europa.eu.

7. Ministerstvo financí posílá do Sněmovny zmírnění sankcí u kontrolního hlášení. Ministerstvo financí České republiky. Ministerstvo financí České republiky [online]. Accessed at 28.2.2016. Available online at: http://www.mfcr.cz.

8. The Methodological Instruction D-21. Finanční správa České republiky [online]. Accessed at 28.2.2016. Available online at: http://www.financnisprava.cz.

\section{Legal acts:}

1. Act no. 235/2004 Coll., On Value Added Tax, as amended.

2. Act no. 280/2009 Coll., The Tax Code, as amended.

3. Council Directive 2013/42/EU of 22 July 2013.

4. European Convention for the Protection of Fundamental Human Rights.

5. Protocol no. 7 to the European Convention for the Protection of Fundamental Human Rights.

\section{Judicial decisions:}

1. Decision of the Supreme Administrative Court from 24th November 2015, 4 Afs 210/2014.

2. Decision of the European Court for Huma n Rights in case Lucky Dev against Sweden, from 27th November 2014, application no. 7356/10.
3. Decision of the European Court for Huma n Rights in case Scoppola against Italy from 13rd May 2008, application no. 10249/03.

4. Decision of the European Court for Huma $n$ Rights in case X against Germany from 6th October 1967, application no. 2728/1966.

5. Decision of the European Court for Huma $n$ Rights in case Le Petit against the United Kingdom from 5th December 2000, application no. 35574/97.

6. Decision of the European Court for Huma n Rights in case Zaprianov against Bulgaria from $30^{\text {th }}$ September 2004, application no. 41171/98.

Communication from the Commission to the European Parliament and the Council: Akční plán pro posílení boje proti daňovým podvodùm a únikům ze dne 6.12.2012. Evropská Komise. Accessed at 30.2.2016. Available online at: http://ec.europa.eu/taxation_ customs/resources/documents/taxation/tax_fraud_evasion/com_2012_722_cs.pdf.

2 Kdo podává kontrolní hlášení? Finanční správa České republiky [online]. Accessed at 30.2.2016. Available online at: http://www.financnisprava.cz/cs/dane-a-pojistne/dane/ dan-z-pridane-hodnoty/kontrolni-hlaseni-DPH/kdo-podava-kontrolni-hlaseni.

3 Kontrolni hlášení: aktuální statistiky z prvního podávání. Finanční správa České republiky [online]. Accessed at 28.2.2016 Available online at:http://www.financnisprava. cz/ cs/financni-sprava/pro-media/tiskove-zpravy/2016/kontrolni-hlaseni-aktualni-statistiky-z-7229.

4 Dưvodová zpráva k návrhu zákona, kterým se mèní zákon č. 235/2004 Sb., o dani $z$ přidané hodnoty, ve znění pozdějšich prèdpisů, a dalši souvisejicí zákony. Poslanecká sněmovna Parlamentu České republiky, sněmovní tisk č. 291 [online]. Accessed at 28.2.2016. Available online at: http://www.psp.cz/sqw/text/tiskt.sqw?O=7ひC$T=291 \leftrightarrow C T 1=0$.

Ministerstvo financí posílá do Sněmovny zmírněni sankcí u kontrolního hlášení. Ministerstvo financí České republiky [online]. Accessed at 28.2.2016. Available online at: http://www.mfcr.cz/cs/aktualne/tiskove-zpravy/2016/ministerstvo-financi-posila-dosnemovny-23665.

Důvodová zpráva $k$ návrhu zákona, kterým se mèní některé zákony v souvislosti s príijetím celního zákona. Poslanecká sněmovna Parlamentu České republiky, sněmovní tisk č. 717 [online]. Accessed at 28.2.2016 Available online at: http://www.psp.cz/sqw/ text/ tiskt.sqw? $O=7 \triangleleft C T=717 \hookleftarrow C T 1=0$.

The Methodological Instruction D-21. Finanční správa České republiky [online]. Accessed at 28.2.2016. Available online at: http://www.financnisprava.cz/assets/cs/prilohy/ d-zakony/Pokyn_GFR_D-21.pdf.

8 See deccision of the Supreme Administrative Court from 24th November 2015, No. 4 Afs 210/2014.

9 Evropská úmluva o lidských právech: komentáŕ. 1. vyd. Praha: C.H. Beck 2012, s. $846-847$.

${ }^{10}$ Důvodová zpráva na straně 70 uvádí, že "[t]ato pokuta je koncipována jako sankce vznikajići ze zákona (ex lege). Jde o obdobnou konstrukci, kterou lze nalézt u pokuty za opoždèné tvrzení daně (\$2 250 daňového řádu) či u penále (\$251 daňového rádu)".

${ }^{11}$ Dưvodová zpráva $k$ vládnímu návrhu zákona o evidenci tržeb. Poslanecká sněmovna Parlamentu České republiky, snèmovní tisk č. 513 [online]. Accessed at 28.2.2016 Available online at: http://www.psp.cz.

12 Specific form of cash register was introduced in Slovakia in 1995 hence the Slovak financial bodies gradually tightens financial obligations related to electronic record of sales. 